\title{
Evolution of Numeracy and the National Numeracy Network
}

\author{
Bernard L. Madison \\ University of Arkansas, bmadison@uark.edu \\ Lynn Arthur Steen \\ St. Olaf College, steen@stolaf.edu
}

Follow this and additional works at: https://digitalcommons.usf.edu/numeracy

Part of the Mathematics Commons

\section{Recommended Citation}

Madison, Bernard L., and Lynn A. Steen. "Evolution of Numeracy and the National Numeracy Network." Numeracy 1, Iss. 1 (2008): Article 2. DOI: http://dx.doi.org/10.5038/1936-4660.1.1.2 


\title{
Evolution of Numeracy and the National Numeracy Network
}

\begin{abstract}
The National Numeracy Network grew from heightened awareness of the complex and sophisticated nature of quantitative literacy and the resulting need for interdisciplinary attention to education for quantitative literacy in schools and colleges. This complexity and sophistication applies especially to the US where it is fueled by an agile economy and the needs of a democratic society. This paper describes the environment surrounding the National Numeracy Network's establishment, some of its activities, and some complementary and synergistic actions by other professional societies. The paper concludes with a sample of quantitative literacy programs in colleges and universities
\end{abstract}

\section{Keywords}

numeracy, quantitative literacy, history

Creative Commons License

(c) (1) (9)

This work is licensed under a Creative Commons Attribution-Noncommercial 4.0 License 


\section{Historical Roots}

The historical roots of quantification in western society extend at least as far back as the clock and cannon builders of the thirteenth century (Crosby 1997, 18). In succeeding centuries, as astronomers and cartographers plied their trades, quantitative descriptors took on special value in commerce and intellectual society. Noteworthy even then is the disconnect from formal mathematics, which at that time had been developed and practiced for more than a millennium without significant demand for quantification in society. Neither the geometry of Euclid nor the genius of Archimedes provided impetus or means for quantification of western society.

The Renaissance began to build some of these missing connections. In the middle of the seventeenth century, a French nobleman with a taste for both gambling and mathematics challenged the famous philosopher-mathematician Blaise Pascal to solve the two-hundred year old puzzle of how to divide the stakes of an unfinished game of chance (Bernstein 1996, 3). Pascal turned for help to lawyer and mathematician Pierre de Fermat, and the theory of probability emerged from this collaboration. Numbers then became much more than a tool for measuring time and distance: they offered a means to manage risk and forecast the future. Indeed, in 1953, economic Nobelist Kenneth Arrow used tools of quantification to articulate a world in which every potential outcome would have a predictable price tag. This idealized "complete market" is a direct albeit distant descendent of the nobleman's unfinished games of chance. It is the ultimate extension of a seemingly trivial pursuit (Surowiecki 2001).

Motivation for the kind of thinking exemplified by Arrow's complete market concept stems from the proclivity of United States (US) citizens toward numbers and calculation. Patricia Cohen, in her book A Calculating People: The Spread of Numeracy in Early America, describes the young Frenchman Alexis de Tocqueville's impressions of 1830 Americans. "Unceasingly they weighed risks, computed advantages, and gauged the utility of any particular course of action ... Their minds were accustomed to definite calculations" (Cohen 1982, 3). In the intervening decades, the management and marketing of risk in the agile US economy have magnified the importance of quantitative skills.

Classical education in the US and Europe did not focus on competencies such as numeracy until the latter part of the twentieth century when numeracy became a concern in the United Kingdom and in the US. After national and international surveys and tests revealed serious weaknesses in people's abilities to understand commonplace quantitative analyses and arguments, some schools and colleges began to make curricular changes. At the beginning of the twenty-first century, several initiatives in the US aimed at improving literacies, particularly quantitative literacy, as numeracy was more commonly called in the US. One of 
these initiatives, led by Robert Orrill as director of the National Council on Education and the Disciplines (NCED), included establishing the National Numeracy Network (NNN), an interdisciplinary organization whose mission was to promote education for numeracy, or quantitative literacy. Our purpose here is to describe the developments that surrounded NNN's creation and detail its history up to this point. We begin with a discussion of the evolution of the concept of numeracy, interrupted with an account of US developments other than the creation of NNN, and finish with some details of NNN's history and an annotated list of QL programs in various colleges and universities.

\section{Evolution of Numeracy Concept}

Although the roots of quantitative literacy (hereafter, QL) extend back centuries, demand for QL in its present form has taken shape only in recent decades. In a very real sense, the need for a high level of quantitative literacy is an American characteristic, reinforced by individual freedoms, economic competitiveness, and the lack of economic safety nets. QL offers tools for survival in a Darwinian society.

Internationally, the concept of numeracy (or QL) has evolved over the past half century. Maguire and O'Donoghue (2002) divide this evolution into three phases: formative, mathematical, and integrative. The formative phase began when the term numeracy was first used in the 1959 "Crowther Report" on the education of children ages 15-18 in the United Kingdom (Ministry of Education 1959). This report described numeracy as "the mirror image of literacy," intended to include "not only the ability to reason quantitatively but also some understanding of scientific method." In this upper secondary school context, both literacy and numeracy signify abilities to communicate at a substantial level, especially about issues that arise in daily life. As literacy meant more than just the ability to read and write, so numeracy meant more than just the third "R"- the ability to add, subtract, multiply, and divide.

Unfortunately-perhaps inevitably-operational conceptions of numeracy following the Crowther Report gradually lost this expectation of sophisticated problem solving. Numeracy gradually came to mean just simple arithmetic skills normally acquired in childhood, what Evans (2000) termed the "limited proficiency" model of numeracy. For many people, and in many parts of the world, numeracy still has this limited meaning. ${ }^{1}$

\footnotetext{
${ }^{1}$ Many mathematicians, for example, view numeracy as inherently elementary and thus the responsibility of K-12 schools rather than colleges. Discussions at a 2004 international workshop, Numeracy and Beyond, held in Banff, Canada, were hampered greatly because of these conflicting views of the nature and complexity of numeracy.
} 
Some two decades after the word numeracy was first introduced, another British government report sought to revive its original meaning, this time in the specific context of mathematics education. This influential report identified two key characteristics of a numerate individual: the ability to use mathematics in everyday life and to understand and appreciate information presented in mathematical terms (Cockroft 1982), ushering in the mathematical phase of numeracy. Over the past two decades this mathematical context has dominated numeracy surveys and literacy testing in Western Europe and the US.

Further arguments for focusing mathematics education in a cross-disciplinary and functional direction emerged in a US report on "what work requires of schools" that stressed practical competencies (in, e.g., resources, information, systems, and technology) built on a broad foundation that included basic skills, decision making, and problem solving (SCANS 1991). The emphasis on numeracy as a functional skill-now giving rise to the term "functional mathematics" (Murnane and Levy 1996; Forman and Steen 1999)—dominates QL assessments and has influenced many state mathematics standards.

In 2000 the Organization for Economic Co-operation and Development (OECD) launched yet another international survey of student performance: the Program for International Student Assessment (PISA). Designed to assess the readiness of 15-year-olds for life beyond school, PISA is designed to focus on a different profile of literacies: reading, mathematics, and science. The mathematics literacy section focuses on functional mathematics: it looks less at what mathematics students know and more at what students can do with the mathematical knowledge they have acquired (PISA 2000). The US was among 43 participating countries in the first PISA survey in 2000, 41 in the second in 2003, and 57 in the third in 2006. In 2003, the US ranked $28^{\text {th }}$ in terms of the percentage of students at each level of proficiency on the mathematics scale. In 2006, the mean score on mathematics by US students was $35^{\text {th }}$ out of 57 countries, 25 th out of the 30 OECD member countries, and statistically significantly below the OECD average (PISA 2006).

In early 2003, the National Assessment of Adult Literacy (NAAL) was administered to US college students. Among many soft spots revealed by this investigation, the most troubling was quantitative literacy. This study showed that 20 percent of students completing four-year degrees and 30 percent of students earning two-year degrees operate only at the basic level of quantitative literacy. These college graduates are not able, for example, to estimate if their car has enough gasoline to get to the next gas station (AIR 2006; Baer et al. 2006). 


\section{Twentieth Century US and More Complex QL}

In the US, shortly after the Cockroft report appeared, the National Assessment of Educational Progress (NAEP) conducted a pioneering inventory of the literacy skills of young adults (Kirsch and Jungeblut 1986). This study dispelled the old notion that individuals are either literate or illiterate by documenting empirically that literacy varies both in degree and kind. NAEP identified three kinds of literacy skills - termed prose literacy, document literacy, and quantitative literacy - and developed for each a continuum (or scale) ranging from quite limited to very high. In this study, quantitative literacy meant the kind of knowledge and skills needed to balance a checkbook, to calculate a tip, or to determine the amount of interest from a loan advertisement.

NAEP's innovative tripartite scales for literacy studies were employed in several subsequent assessments, including a study of the literacy needs of job seekers (Kirsch, Jungeblut, and Campbell 1992), the first National Adult Literacy Survey (NALS) (Kirsch et al. 1993), and the first International Adult Literacy Survey (IALS) (OECD 1995). As the first multi-national assessment of adult literacy, IALS ${ }^{2}$ sought to develop scales for comparisons of literacy performance among people with a wide range of abilities, and to compare the three dimensions of literacy across cultures and languages (HRSDC 1994).

One result of the Cockroft report was the introduction of statistics into the British national curriculum, emphasizing a hands-on practical approach to statistical applications and data analysis. This was part of the motivation for the American Statistical Association (ASA) project in the mid-1980s entitled Quantitative Literacy. This effort, funded by the National Science Foundation, produced materials and workshops to introduce middle and high school teachers of mathematics to basic concept of data analysis and probability. Following this, the Joint Committee of ASA and the National Council of Teachers of Mathematics (NCTM) quantitative literacy project served as a model for the data analysis and probability strand of the 1989 NCTM Curriculum and Evaluation Standards for School Mathematics (NCTM 1989). This strand appears even stronger in the 2000 NCTM standards (NCTM 2000) (Scheaffer 2003). The connections between QL and statistics are numerous, not only historically, but also in pedagogical practice. As Richard Scheaffer $(2003,146)$ points out, "there are strong ties between statistical thinking, data analysis, and quantitative literacy in terms of historical developments, current emphases, and prospects for the future."

${ }^{2}$ IALS was conducted in eight industrialized countries: Canada, Ireland, Germany, the Netherlands, Poland, Sweden, Switzerland, and the United States. 
The relationship between mathematics and QL in the US collegiate curriculum has not been as clear as the relationship between statistics and QL as a part of the K-12 curriculum. Although mathematics for general education always has been a part of the US college curriculum, expectations in QL as a part of an undergraduate degree have become more prominent in the past few decades. In 1989 the Mathematical Association of America (MAA), partly in conjunction with the appearance of the 1989 NCTM Standards, appointed a Subcommittee on Quantitative Literacy Requirements (QL Subcommittee) of the Committee on the Undergraduate Program in Mathematics (CUPM). This subcommittee began by considering the question: What quantitative literacy requirements should be established for all students who receive a bachelor's degree?

In 1994, the QL Subcommittee issued a report (Sons 1996), "Quantitative Reasoning for College Graduates: A Complement to the Standards," which highlighted four conclusions:

- Colleges and universities should treat quantitative literacy as a thoroughly legitimate and even necessary goal for baccalaureate graduates.

- Colleges and universities should expect every college graduate to be able to apply simple mathematical methods to the solution of real-world problems.

- Colleges and universities should devise and establish quantitative literacy programs each consisting of foundation experience and a continuation experience, and mathematics departments should provide leadership in the development of such programs.

- Colleges and universities should accept responsibility for overseeing their quantitative literacy programs through regular assessments.

These conclusions emphasize the collegiate responsibility for QL education, but the report did not have much immediate effect on collegiate mathematics. It was not, for example, endorsed by the MAA Board of Governors nor formally published as one of MAA's core curriculum reports. QL continued to be poorly understood and largely ignored in college mathematics curricula.

Although the QL Subcommittee continued to work after 1994, the need for a more substantial presence of QL in MAA activities was evident from the work produced by the NCED initiative and the substantial attention to general education issues in the CUPM Curriculum Guide 2004. This need led to creation of the SIGMAA QL, a special interest group of MAA members. SIGMAA QL was formed by action of the MAA Board of Governors in January 2004 and aims to provide a structure within the mathematics community to identify the prerequisite mathematical skills for QL and find innovative ways of developing and implementing QL curricula. MAA published Current Practices in 
Quantitative Literacy (Gillman 2006), a volume of descriptions of QL programs edited by Rick Gillman, who was a driving force in organizing SIGMAA QL.

\section{Integrative Phase of QL}

Functionality is more complex than any list of specific tasks such as balancing a check book or projecting gasoline requirements. The mathematical demands of everyday life, especially in the quantitatively demanding US society, require more than basic numeracy. The realization that numeracy is a sophisticated skill requiring more than basic mathematics led to the current conception of numeracy - what Maguire and O'Donoghue (2002) call the integrative phase. This conception is articulated in the vision of the National Numeracy Network as "the power and habit of mind to search out quantitative information, critique it, reflect upon it, and apply it in their public, personal and professional lives," which draws on the wording by Cremin (1988) in describing what he calls "liberating" literacy.

These three conceptions of numeracy-formative, mathematical, and integrative - continue to be entangled in the public mind. In discussions of US education, the term quantitative literacy is much more common than numeracy, especially in recent years, although both terms continue to be used as synonyms. Some view quantitative literacy as the more inclusive term, while others (perhaps fearing the association of quantitative with mathematical) prefer the alternative expression quantitative reasoning. Robert Orrill has described QL as a cultural field where language and quantitative constructs merge and are no longer one or the other. From this perspective, "quantitative literacy" is a more inclusive term than the narrower word "numeracy." Others view QL as part of a portfolio of literacies (e.g., historical, information, communicative, scientific, document, financial, and quantitative), much as we have come to recognize multiple intelligences such as logical-mathematical, linguistic, musical, and spatial (Gardner 1993). In recent years quantitative literacy has received increasing attention, in part because it is most notably lacking and most critically needed.

Near the end of the twentieth century popular publications such as those of John Allen Paulos (1988, 1992, 1996), scholarly analyses of educational circumstances (Porter 1995; Wise 1995), and reports by professional societies (Sons 1996; NCTM 1989, 2000) highlighted the importance of QL but left it poorly understood and entangled with more traditional school subjects such as mathematics and statistics. It was in this context that the College Board, under the leadership of Robert Orrill in the Office of Academic Affairs, launched an inquiry into the meaning of quantitative literacy and its implications for secondary and postsecondary education. 
The first questions arose among scientists who were advising the College Board on modernizing the Advanced Placement (AP) examinations in science. They worried that these examinations, developed before the era of personal computers, might not reflect appropriately the quantitative demands of modern science. So the science advisors asked the mathematics advisors to help them think through the distinctions between mathematics - which they understoodand quantitative literacy, which they found problematic. The result of this inquiry was not the crisp description that some hoped for, but a wide-ranging set of essays entitled Why Numbers Count: Quantitative Literacy for Tomorrow's America written by diverse consumers of quantitative information (Steen 1997). Their observations about quantitative literacy, as Orrill notes in his foreword, "challenge traditional approaches to orienting the mathematics curriculum in this country."

\section{NCED and NNN}

Subsequent to the 1997 Why Numbers Count, with support from the Pew Charitable Trusts, Orrill founded and directed the National Council on Education and the Disciplines (NCED) whose goal was to promote discussion about core literacies at the transition from secondary to postsecondary education. ${ }^{3}$ The primary focus of NCED became quantitative literacy. Its first initiative, Mathematics and Democracy: The Case for Quantitative Literacy, offered an apologia for QL together with responses from professionals in a variety of careers (Steen 2001). Subsequently, in cooperation with the National Research Council and the MAA, NCED hosted a national forum on quantitative literacy at the National Academy of Sciences in Washington, DC (Madison and Steen 2003). A brief fourth volume, Achieving Quantitative Literacy: An Urgent Challenge for Higher Education, offered a synopsis of major issues raised at the Washington forum in order to create a national debate about the place of quantitative literacy in higher education (Steen 2004). This volume completed the QL inquiry instigated years earlier by the College Board's worried science advisors.

NNN began in 2000-01 under the leadership of Susan Ganter at Clemson University as the outreach component of the NCED initiative in quantitative

\footnotetext{
${ }^{3}$ NCED's goals were much broader than promotion of QL. Hosted by the Woodrow Wilson National Fellowship Foundation, NCED "drew on the energy and expertise" of scholars and educators associated with the Foundation "to advance a vision that will ... strengthen K-16 education in the United States." NCED focused on "the continuity and quality of learning" in grades 11-14. "At the heart of its work is a national reexamination of the core literacies quantitative, scientific, historical, and communicative - that are essential to the coherent, forward-looking education all students deserve."
} 
literacy. Modeled very loosely on the National Writing Project, ${ }^{4} \mathrm{NNN}$ organized a consortium of numeracy programs and QL centers at colleges, universities, and other professional organizations. The goals of NCED's NNN consortium were:

- to assist sites with efforts to translate numeracy from aspiration to educational practice;

- to facilitate communication for disseminating promising educational practices;

- to encourage cross-sector interest in and attention to numeracy among schools, colleges, civic groups, business and industry; and

- to support research, reports, and publications to increase understanding and significance of numeracy.

Four centers received small start-up grants from NCED to provide technical support and help launch the national effort:

- Dartmouth College, Hanover, NH, provided a Web site host for QL materials being developed at other NNN Centers and elsewhere around the country.

- Trinity College, Hartford, CT, developed new courses in disciplines other than mathematics that incorporate quantitative reasoning and ran QL workshops for teachers in greater Hartford area schools.

- University of Nevada, Reno, NV, produced QL modules for use in (nonmathematics) college classes and teacher workshops using examples from popular sources that are appropriate for grades 7-14.

- The Washington Center, Evergreen, WA, created professional development opportunities for faculty from two- and four-year colleges to learn about QL and incorporate it into the curriculum of their courses.

Subsequently, NCED identified 18 "first-tier" programs which were judged to be more highly developed and able to assume leadership roles in developing and disseminating resources for QL education. In addition, 19 second-tier programs were judged as less developed but promising in contributing to networking for QL education. From its beginning, NNN was guided by a national advisory board consisting of representatives from the NNN member sites.

After the NCED project was completed, the National Numeracy Network (NNN) was established formally as a membership organization at meeting held at Moose Mountain Lodge near Dartmouth College in June 2004. Aiming to be complementary to rather then competitive with existing QL-supporting organizations including ASA and SIGMAA QL, NNN emphasized in its mission

\footnotetext{
${ }^{4}$ The National Writing Project (NWP) is a network of programs (sites) linked with common program elements for the purpose of improving writing in America. Using a professional development model, NWP builds the leadership, programs, and research needed for teachers to help their students become successful writers.
} 
that it promotes education for QL across all disciplines. In 2004 NNN by-laws were adopted to further the following vision and mission:

- Vision. The National Numeracy Network envisions a society in which all citizens possess the power and habit of mind to search out quantitative information, critique it, reflect upon it, and apply it in their public, personal, and professional lives.

- Mission. The National Numeracy Network promotes education that integrates quantitative skills across all disciplines and at all levels. To this end the Network supports faculty development, curriculum design, assessment strategies, education research and systemic change. The Network is the professional organization serving and promoting collaborations among those students, educators, academic centers, educational institutions, professional societies and corporate partners sharing our vision. The Network also strives to keep issues of quantitative literacy at the forefront of national and international conversations about educational priorities.

NNN is incorporated in the State of Washington and has 501-3(c) status with the IRS; its Web site is www.math.dartmouth.edu/ nnn/. The initial officers and board of directors for 2004-2005 were:

- President: Bernard L. Madison, Mathematics, University of Arkansas

- Secretary-Treasurer: Rebecca Hartzler, Physics, Seattle Community College

- Director: H. L. (Len) Vacher, Geology, University of South Florida

- Director: Dorothy Wallace, Mathematics, Dartmouth College

- Director: Kim Rheinlander, Center for Mathematics and Quantitative Education, Dartmouth College

A list of subsequent officer and boards of directors is given below in Appendix A.

In keeping with the goal of connecting numeracy with diverse disciplines, meetings of the independently incorporated National Numeracy Network have been held in conjunction with various other meetings:

- June 18-19, 2005. First meeting of NNN was held in conjunction with a professional development workshop on QL sponsored by the MAA Professional Enhancement Program (PREP) at Macalester College, St. Paul, MN.

- August 6, 2006. Second Meeting of NNN was held in conjunction with the Joint Statistics Meetings in Seattle, WA.

- April 5, 2007. Third Meeting of NNN was held in conjunction with meetings of Midwest Sociological Society and North Central Sociological Association in Chicago, IL, and in cooperation with the QL special interest group of the MAA (SIGMAA). 
At its second meeting, NNN decided to develop a new online periodical as a way of enhancing understanding of the many facets of QL programs, in a response to a proposal to the board by the University of South Florida (USF) Libraries. The editors, H.L. Vacher (USF) and Dorothy I. Wallace (Dartmouth) met with several associate editors and Todd Chavez, a Director of the USF Libraries, at Dartmouth College in December 2006. Among the results of that meeting were a name for the journal, Numeracy: Advancing Education in Quantitative Literacy; decisions on policies, review procedures, and schedules; and plans for the first issue targeted for January 2008. The invitation for the authors to submit this paper for the inaugural issue was another result of that meeting.

\section{QL Programs}

As the U.S. continues its quest to improve education, programs exploring different approaches to numeracy and quantitative literacy continue to expand and evolve. To help support this growing interest the MAA has created a Web site with key links to QL programs and publications (www.maa.org/ql/index.html), including the National Numeracy Network. One of these links offers a list of various QL programs at U.S. colleges and universities. Most of the following programs are described in more detail by Gillman (2006).

- Augsburg College (Minneapolis, MN). QR is a skill in the core curriculum required of all Augsburg students. Select courses across the curriculum focus on developing QR skills: for example, Persuasion, Quantitative Journalism, Community Health, Physics for the Fine Arts, Psychological Foundations of Music, Statistical Literacy, and Math of Interest. Contact: Tracy Bibelnieks < bibelnie@ augsburg.edu>. In addition, the W. M. Keck Statistical Literacy Project, supported by the W.M. Keck Foundation, has as it goal "to develop statistical literacy as an interdisciplinary curriculum in the liberal arts." This project involves an ongoing course in Statistical Literacy. Contact: Milo Schield <schield@augsburg.edu>. URL: www.augsburg.edu/statlit.

- Carleton College (Northfield, MN). A FIPSE-supported initiativeQuantitative Inquiry, Reasoning, and Knowledge (Quirk) — prepares students to use quantitative information in a principled manner in the evaluation and presentation of arguments. New first-year seminars and revised upper-level courses involve students in applications of quantitative reasoning. Papers submitted to meet an existing portfolio requirement are being used to assess whether and how students use quantitative evidence in their regular assignments. Contact:Neil Lutsky <nlutsky@ carleton.edu>. URL: www.go.carleton.edu/quirk. 
- Colby-Sawyer College (New London, NH). A QL requirement consists of one mathematics course (most of which involve QL) plus other quantitative exercises encountered across the curriculum and in student activities. To achieve the latter goal, $30 \%$ of the faculty (representing all departments) plus student service staff participated in a recent NSF-funded workshop to develop or adapt QL projects. Progress in QL is assessed in many first-year seminars and in senior capstones. Contact: Semra Kılıç-Bahi <skilicbahi@colby-sawyer.edu>. URL: www.colby-sawyer.edu/academic/admin/ liberaleducation/proficiencies.html.

- Central Washington University (Ellensburg, WA). A broad program designed to develop and assess students' capabilities in "analytical thought, symbolic reasoning, and quantitative analysis." Contact: Stuart Boersma <boersmas@cwu.edu>, Aaron Montgomery <montgoaa@cwu.edu>. URL: www.cwu.edu/ avpugrad/assessment.html.

- Hamilton College (Clinton, NY). A quantitative literacy requirement which includes passing either a QSkills Exam, a designated "Q" course, or a noncredit QLit Tutorial. A QLit Center offers drop-in peer tutoring to support quantitative courses. Contact: Mary O'Neill <moneill@ hamilton.edu>. URL: www.hamilton.edu/academics/resource/qlit/.

- Hollins University (Roanoke, VA). All students must satisfy a basic quantitative reasoning $(\mathrm{q})$ and an applied quantitative reasoning $(\mathrm{Q})$ requirement. Trained student tutors in a QR Center assist students in achieving these requirements. An NSF grant supported the original development of $\mathrm{Q}$ courses across the curriculum; there are now approximately 40 such courses. Contacts: Phyllis Mellinger $<$ pmellinger@hollins.edu> or Caren Diefenderfer <cdiefenderfer@hollins.edu>. URL: www1.hollins.edu/depts/qr/index.html.

- James Madison University (Harrisonburg, VA). A systemic, institutionwide approach to quantitative literacy, including assessment and development of a QR instrument and a curriculum designed for elementary and middle school teachers. Contacts: David Brakke <brakkedf@jmu.edu> (for program); Donna Sundre <sundredl@jmu.edu $>$ (for assessment); David Carothers < carothdc@jmu.edu $>$ (for teacher curriculum).

- Keene State College (Keene, NH). A QL initiative is a foundational component of Keene State's new Integrative Studies Program. All Keene students will be required to take an outcomes-based quantitative literacy course in their first year. Faculty from disciplines across the campus will teach the QL courses. Contacts: Eileen Phillips <ephillips@keene.edu>; Dick Jardine <rjardine@keene.edu>; Mike Cullinane <mcullina@keene.edu>.

- Lawrence University (Appleton, WI). A "Mathematical Reasoning or Quantitative Analysis Requirement" has stimulated discussion about what quantitative reasoning means and how to foster it. Course offerings include statistics across the curriculum in three flavors: for economics, for social science, and for natural science. Contact: Joy Jordan $<$ joy.jordan@lawrence.edu>. 
- Macalester College (St. Paul, MN). A college-wide graduation requirement in Quantitative Thinking focuses on application to policy analysis. Examples of emphases include: describing the world quantitatively, evaluating sources and quality of data, association and causation, trade-offs, uncertainty and risk, and estimation/modeling/scale. Contact: David Bressoud <bressoud@macalester.edu>, URL: www.macalester.edu/qm4pp/program/.

- Northern Illinois University (DeKalb, IL). A quantitative literacy requirement aims to help all students increase their ability to reason logically and quantitatively with an emphasis on solving problems common in life experiences. All students take at least one course and most take follow-up requirements according to their majors. Contact: Linda Sons <sons@math.niu.edu>.

- Skidmore College (Skidmore, NY).The two-level quantitative reasoning requirement is as follows. Before the end of the sophomore year students must demonstrate basic quantitative competence either via sufficient SAT score, or by passing an in-house exam, or by passing a specific remedial quantitative reasoning course. Before the end of the junior year, each student must pass a "QR2" course that devotes a significant portion of the syllabus to quantitative methods and issues. These courses are available in many departments. Contact: Gove Effinger <effinger@skidmore.edu>.

- Trinity College (Hartford, CT). Two levels of quantitative literacy courses are offered through the Aetna Math Center, as well as Center-sponsored quantitative enrichment throughout the curriculum, including the First Year Program and courses in human rights, political science, history, classics, sociology and international studies. URL: www.trincoll.edu/depts/mcenter/. Contact: Judith Moran <judith.moran@mail.trincoll.edu>.

- University of Arkansas (Fayetteville, AR). One version of a course entitled "Mathematical Reasoning in a Quantitative World," which satisfies the mathematics requirement for the BA degree in arts and sciences, began experimentally in 2004 as quantitative literacy for journalists. Informally known as NewsMath, this section uses newspaper and magazine articles brought to class by the instructor and students for discussion and critique of the quantitative content. There is a heavy focus on reasoning as opposed to algorithms. Contact: Bernard Madison <bmadison@uark.edu>.

- University of South Florida (Tampa, FL). The College of Arts and Sciences at USF is implementing a new general education curriculum in which each course that is certified for general education has to show that it meets a threshold number of distinct dimensions, one of which is quantitative literacy. Contact: Bob Potter <potter@ cas.usf.edu>.

- University of Washington, Bothell (Bothell, WA). A "QR across the curriculum" program is coordinated through a Quantitative Skills Center that supports both students and faculty in any course requiring quantitative skills or reasoning. Contact: Cinnamon Hillyard <chillyard@uwb.edu>. URL: www.uwb.edu/qsc. 
- Virginia Commonwealth University (Richmond, VA). A general education requirement on "quantity and form" includes courses in mathematics, statistics, and critical thinking. URL: www.has.vcu.edu/students/ug_edu/gen_edu/quantity_form.html. In addition, the Virginia Adult Learning Resource Center (VALRC) conducts a state-funded training initiative, called the Virginia Numeracy Project, to provide professional development on numeracy instruction to educators of adult literacy students. Four strands are offered: Numbers and Number Sense; Patterns and Algebra; Measurement and Geometry; Data and Statistics. Workshops are free to Virginia Adult Education practitioners. VALRC: 800-237-0178. Contact: Aimee Ellington<ajellington@vcu.edu>.

- Yale University (New Haven, CT). Beginning with the class of 2009, undergraduates must complete, by the end of their junior year, two courses in which the majority of exercises are designed to promote the development of QR skills. Most of these courses are in mathematics, statistics, algorithms, and formal symbolic logic. Students cannot place out of the QR requirement, but are expected to choose QR courses that will build on existing skills or provide exposure to new areas of QR. Placement and assessment tools are currently under development. Contact: Frank Robinson $<$ frank.robinson@yale.edu>.

\section{Conclusion}

From roots in quantification by clock makers and cannon builders of the middle ages and the development of probability in the Renaissance, the modern need for stronger QL education emerged, fed by the American proclivity for numbers and calculations. In the latter half of the $20^{\text {th }}$ Century, the educational concept of numeracy or QL evolved after introduction in two reports on schools in the United Kingdom. First appearing in the US K-12 curriculum as a strand in the NCTM Standards (1989 and 2000) developed by ASA and NCTM, QL was recognized by the MAA and NCED as an issue for colleges. Subsequently, both the MAA and NCED spawned organizations to promote collegiate attention to QL: SIGMAA QL as a special interest group in MAA and NNN by NCED. The interdisciplinary focus of NNN sets it apart, making it an interest of many but a passion of a few, much akin to its cause - quantitative literacy. Up to this point, NNN has promoted interaction among academics in various disciplines including mathematics, statistics, social sciences, some humanities, and some natural sciences. NNN is embarking on documenting and disseminating scholarship in QL education; its first major initiative is this journal.

\section{Acknowledgments}

The authors gratefully acknowledge the comments and suggestions of the editor and anonymous referees that significantly improved the final version of this 
paper. We also take the opportunity to salute the enormous contributions that Robert Orrill has made in forging the national initiative on quantitative literacy that included founding of the National Numeracy Network.

\section{References}

AIR (American Institutes for Research). 2006. New study of the literacy of college students finds some are graduating with only basic skills. http://www.air.org/news/documents/Release200601pew.htm.

Baer, Justin D., Stéphane Baldi, and Andrea L. Cook. 2006. The literacy of America's college students. Washington, DC: American Institutes for Research.

Bernstein, Peter L. 1996. Against the gods: The remarkable story of risk. New York, NY: John Wiley.

Cockcroft, Sir Wilfred H. 1982. Mathematics counts. London: Her Majesty's Stationery Office.

Cohen, Patricia Cline. 1982. A calculating people: The spread of numeracy in early America. Chicago, IL: University of Chicago Press, 1982; New York, NY: Routledge, 1999.

Cremin, Lawrence A. 1988. American education: The metropolitan experience 1876-1980. New York, NY: Harper \& Row.

Crosby, Alfred W. 1997. The Measure of Reality: Quantification and western society, 1250-1600. Cambridge, UK: Cambridge University Press.

Evans, Jeff. 2000. Adults mathematical thinking and emotions: A study of numerate practices. London: Routledge/Falmer, Taylor \& Francis Group.

Forman, Susan L. and Lynn Arthur Steen. 1999. Beyond eighth grade: Functional mathematics for life and work. Berkeley, CA: National Center for Research in Vocational Education, 1999. (Also in Learning mathematics for a new century, ed. Maurice Burke, 127-157. Reston, Va: National Council of Teachers of Mathematics, 2000).

Gillman, Rick. 2006. Current practices in quantitative literacy. Washington, DC: Mathematical Association of America.

Gardner, Howard. 1993. Multiple intelligences: The theory in practice. New York, NY: Basic Books.

HRSDC (Human Resources and Social Development Canada). 1994. Reading the future: A portrait of literacy in Canada-Backgrounder: IALS: The first of its kind. http://www.hrsdc.gc.ca/en/hip/lld/nls/Surveys/ialscrbk.shtml.

ILSS 2000. International life skills survey. Ottawa: Statistics Canada Policy Research Initiative. 
Kirsch, Irwin S. and Ann Jungeblut. 1986. Profiles of America's young adults. National Assessment of Educational Progress. Princeton, N.J.: Educational Testing Service (ETS Report No. 16-PL-02). http://www.ets.org/Media/ Research/pdf/LITERACY_PROFILES.pdf

—, and Anne Campbell. 1992. Beyond the school doors: The literacy needs of job seekers served by the U.S. Department of Labor. U.S. Department of Labor. Princeton, N.J.: Educational Testing Service. http://wdr.doleta.gov/ opr/FULLTEXT/1992_03.pdf

$\longrightarrow$, L. Jenkyns, and A. Kolstad. 1993. Adult literacy in America. Report of the National Adult Literacy Survey (NALS). Washington, DC: U.S. Department of Education, National Center for Education Statistics. http:// nces.ed.gov/pubsearch/pubsinfo.asp?pubid=93275

Madison, Bernard L. and Lynn Arthur Steen, eds. 2003. Quantitative literacy: Why numeracy matters for schools and colleges. Princeton, NJ: National Council on Education and the Disciplines.

Maguire, T. and J. O'Donoghue, J. 2002. A grounded approach to practitioner training in Ireland: Some findings from a national survey of practitioners in adult basic education." In Numeracy for empowerment and democracy? Proceedings of the $8^{\text {th }}$ International Conference of Adult Learning Mathematics, ed. L. O. Johansen and T. Wedege, 120-132. Roskilde, Denmark: Roskilde University, Centre for Research in Learning Mathematics. Stevenage, UK: Avanti Books.

Ministry of Education. 1959. 15 to 18: A report of the Central Advisory Committee for Education (England). London: Department of Education and Science.

Murnane, Richard and Frank Levy. 1996. Teaching the new basic skills: Principles for educating children to thrive in a changing economy. New York, NY: Free Press.

NCTM (National Council of Teachers of Mathematics). 1989. Curriculum and evaluation standards for school mathematics. Reston, VA: National Council of Teachers of Mathematics.

2000. Principles and standards for school mathematics. Reston, VA: National Council of Teachers of Mathematics.

OECD (Organization for Economic Cooperation and Development). 1995. Literacy, economy, and society: results of the first International Adult Literacy Survey. Paris: OECD.

Paulos, John Allen. 1988. Innumeracy: Mathematical illiteracy and its consequences. New York, NY: Hill and Wang.

. 1992. Beyond numeracy: Ruminations of a numbers man. New York, NY: Alfred A. Knopf, 1991; Vintage Books. 
C. 1996. A mathematician reads the newspaper. New York, NY: Doubleday.

PISA. 2000. Programme for International Student Assessment. Paris: Organization for Economic Cooperation and Development. http://www .statistics.gov.uk/statbase/Product.asp?vlnk=8169

- 2006. Programme for International Student Assessment. Paris: Organization for Economic Cooperation and Development. http://www .pisa.oecd.org/dataoecd/15/13/39725224.pdf

Porter, Theodore M. 1995. Trust in Numbers: The Pursuit of Objectivity in Science and Public Life. Princeton, NJ: Princeton University Press.

SCANS (Secretary's Commission on Achieving Necessary Skills). 1991. What work requires of schools: A SCANS report for America 2000. Washington, DC: U.S. Department of Labor http://wdr.doleta.gov/SCANS/whatwork/ whatwork.pdf

Scheaffer, Richard. L. 2003. Statistics and quantitative literacy. In Quantitative literacy: Why numeracy matters for schools and colleges, ed. B.L. Madison and L.A. Steen, 145-152. Princeton, NJ: National Council on Education and the Disciplines. http://www.maa.org/Q1/pgs145_152.pdf

Sons, Linda, ed. 1996. Quantitative reasoning for college graduates: A complement to the standards. Washington, DC: Mathematical Association of America. http://www.maa.org/past/ql/ql_toc.html

Steen, Lynn Arthur, ed. 2001. Mathematics and Democracy: The Case for Quantitative Literacy. Princeton, NJ: National Council on Education and the Disciplines. http://www.maa.org/Q1/mathanddemocracy.html

—, ed. 1997. Why numbers count: Quantitative literacy for tomorrow's America. New York, NY: The College Board.

- 2004. Achieving quantitative literacy: An urgent challenge for higher education. Washington, DC: Mathematical Association of America.

Surowiecki, James. 2001. The Financial Page: What Weather Costs. The New Yorker, July 23, p. 29.

Wise, Norton M., ed. 1995. The values of precision. Princeton, NJ: Princeton University Press. 


\section{Appendix}

\section{NNN Officers and Boards of Directors}

2004-05:

President - Bernard L. Madison, Mathematics, University of Arkansas

Secretary-Treasurer - Rebecca Hartzler, Physics, Seattle Community College

Director - H. L. Vacher, Geology, University of South Florida

Director - Dorothy Wallace, Mathematics, Dartmouth College

Director - Kim Rheinlander, Center for Mathematics and Quantitative Education,

Dartmouth College

2005-2006:

President - Bernard L. Madison, Mathematics, University of Arkansas

Secretary-Treasurer - Rebecca Hartzler, Physics, Seattle Central Community College

Director - David Bressoud, Mathematics, Macalester College

Director - William Frey, Sociology, University of Michigan

Director - Beth Haines, Psychology, Lawrence University

Director - Neil Lutsky, Psychology, Carleton College

Director - Richard Scheaffer, Statistics, University of Florida

Director - Corrine Taylor, Economics, Wellesley College

Director - H. L. Vacher, Geology, University of South Florida

Director - Dorothy Wallace, Mathematics, Dartmouth College

Emeritus Director - Kim Rheinlander, Center for Mathematics and Quantitative

Education, Dartmouth College

2006-2007:

President - Bernard L. Madison, Mathematics, University of Arkansas

Secretary-Treasurer - Rebecca Hartzler, Physics, Seattle Central Community College

Director - David Bressoud, Mathematics, Macalester College

Director - William Frey, Sociology, University of Michigan

Director - Beth Haines, Psychology, Lawrence University

Director - Cinnamon Hillyard, Mathematics, University of Washington-Bothell

Director - John Jungck, Biology, Beloit College

Director - Neil Lutsky, Psychology, Carleton College

Director - Richard Scheaffer, Statistics, University of Florida

Director - Corrine Taylor, Economics, Wellesley College

Emeritus Director - H. L. Vacher, Geology, University of South Florida

Emeritus Director - Dorothy Wallace, Mathematics, Dartmouth College

Emeritus Director - Kim Rheinlander, Center for Mathematics and Quantitative

Education, Dartmouth College 
2007-2008:

President - Corrine Taylor, Economics, Wellesley College

Vice President - Milo Schield, Business Administration, Augsburg College

Secretary - Rebecca Hartzler, Physics, Seattle Central Community College

Treasurer - Cinnamon Hillyard, Mathematics, University of Washington-Bothell

Director - David Bressoud, Mathematics, Macalester College

Director - William Frey, Sociology, University of Michigan

Director - Beth Haines, Psychology, Lawrence University

Director - John Jungck, Biology, Beloit College

Director - Neil Lutsky, Psychology, Carleton College

Director - Richard Scheaffer, Statistics, University of Florida

Emeritus President - Bernard L. Madison, Mathematics, University of Arkansas

Emeritus Director - H. L. Vacher, Geology, University of South Florida

Emeritus Director - Dorothy Wallace, Mathematics, Dartmouth College

Emeritus Director - Kim Rheinlander, Center for Mathematics and Quantitative Education, Dartmouth College 